\title{
Na pele de seda da criação - reescritura como tradução em Cobra Norato, de Raul Bopp
}

Under the silky skin of creation - rewriting as translation in Raul Bopp's Cobra

Norato

Sebastião Edson MACEDO ${ }^{1}$

University of California, Berkeley

\begin{abstract}
RESUMO: Apresento uma leitura do continuado trabalho de reescritura que Raul Bopp conferiu à Cobra Norato, no qual faz a criação do poema mimetizar uma imagem do poemarapisódico ("a pele de seda elástica”) como procedimento de auto-tradução lírica. Exploro o imagismo do poema, percorrendo possibilidades interpretativas sobre uma ética do olhar levada a cabo por um discurso poético que se anuncia "de olhos vendados" e "de corpo aberto". Assim, a reescritura de Bopp permite conceber um trabalho de tradução de uma sensibilidade à materialidade discursiva que lhe serve de substrato, redundando, por sua vez, numa perspectiva do poeta moderno como mediador de corpos em heterodoxas zonas de contato cultural, como a Amazônia.
\end{abstract}

PALAVRAS-CHAVE: Raul Bopp, Cobra Norato, Tradução, Mediação, Ética do olhar

\begin{abstract}
This article presents an analysis of Raul Bopp's Cobra Norato rewriting, in which the poem emulates an image of the rhapsody ("elastic silk skin) as a procedure to a lyric self-translation. It exploits the imagery of the poem through the possible interpretations conceived with an ethical review of a poetic argument that "blindfoldedly" and "overtly" presents itself. Therefore, Bopp's rewriting allows the poet to create a translation work focused on the materiality of the speech, which works as a residue. This results in a perspective of the modern poet as an intermediary of bodies in heterogeneous areas of cultural contact, such as the Amazon.
\end{abstract}

KEYWORDS: Raul Bopp, Cobra Norato, Translation studies, Mediation, Ethical review

\footnotetext{
${ }^{1} \mathrm{Ph} . \mathrm{D}$. in Hispanic Languages and Literatures, with emphasis in Luso-Brazilian Literatures and Culture, University of California, Berkeley, USA. email: sedmacedo@berkeley.edu

Enviado em 20/07/2018 e aprovado em 25/07/2018
} 
A floresta vem caminhando

- Abra-se que eu quero entrar!

(Raul Bopp, Cobra Norato, XVII)

No início de Cobra Norato (1931), logo depois que o eu lírico logra estrangular e entrar na pele do animal encantado que dá nome ao poema rapsódico-dramático de Raul Bopp, anuncia-se uma curiosa exigência: para que o sujeito lírico possa empreender sua jornada pessoal pela selva amazônica e tenha êxito na busca da filha da Rainha Luzia, a quem este aspira como noiva, ele "tem que apagar os olhos primeiro" (I). ${ }^{2}$

Há nessa exigência, sem dúvida, a pronta demarcação de uma fronteira sensorial, e por conseguinte, de um espaço interditado ao olhar desse sujeito cujo propósito pessoal não inspira muita diferença com o dos aventureiros e exploradores. Talvez por isso mesmo, não é apenas o olhar que se interdita, mas certa associação entre o olhar e seu efeito na consciência e na atitude do sujeito, já que o poema vai agenciar logo em seguida a dinâmica do adormecimento, onde se experimenta o relaxamento muscular e a soltura do comando físico geral de si, ao dizer "O sono escorregou nas pálpebras pesadas/ Um chão de lama rouba a força dos meus passos" (idem). Direi, a princípio, que "apagar os olhos" seria um protocolo de ressubjetivação, que implica transitar do âmbito da consciência empírica vigilante para o universo onírico do inconsciente. $\mathrm{O}$ acesso a esse outro território das livres e inesperadas aproximações depende, no poema, de uma alteração no modo como o sujeito convencionalmente dá sentido ao encadeamento dos fenômenos e elabora uma sintaxe do mundo, ou seja, depende de um desmantelo do olhar e, por conseguinte, da leitura da ordem discursiva ali disposta entre as palavras e as coisas. A exigência dessa voz - que se dirige ao herói do poema surgida não se sabe de onde - busca intervir de imediato no corpo do sujeito lírico e reconfigurar, por assim dizer, seu aparato sensorial e mimético.

\footnotetext{
${ }^{2}$ Todas as citações que doravante farei de Cobra Norato referem-se à $18^{\text {a }}$ edição do poema (José Olympio/EdUSP: 1998), curada por Augusto Massi. Após cada citação, aponto entre parêntesis a numeração interna, da seção do poema em que os versos citados aparecem.
} 
Interesso-me aqui por duas reconfigurações do sujeito engendradas pela obstrução de seu sentido visual no limiar da jornada que empreenderá pela selva. Uma, diz respeito à cultura do olhar. Outra, refere-se à experiência do corpo. Tratam-se de dois processos conexos de subjetivação que, como procurarei demonstrar a seguir, radicam no continuado trabalho de reescritura que Raul Bopp conferiu à sua rapsódia, fazendo a (re)criação do poema "esticar a pele de seda elástica", por assim dizer, como possibilidade de interpretação da cultura e do corpo amazônico desde a condição de forasteiro; interpretação esta que tratarei aqui, portanto, na chave da tradução, para explicitar a exterioridade do autor e sua mediação na transitividade entre regimes sensoriais e

estéticos distintos. E, considerando tratar-se ainda de uma tradução que se dá "de olhos vendados" e "de corpo aberto", arrisco sugerir que Raul Bopp estaria nos convidando, afinal, à crítica da mediação de um espaço que nos revela justamente nosso interesse na abertura das possibilidades de percepção e de construção do conhecimento moderno.

\section{Olhar, entrar, sentir}

Começo com uma brevíssima menção a um tópico comum na história das idéias ocidentais: a transformação do olhar como modo de existência ao longo dos séculos. Olhar era um gesto difícil, gozoso e doloroso, podendo ser libertador e mesmo invasivo para as antigas sociedades medievais e, como nos informa o contexto da lírica trovadoresca, estava carregado de tabus morais. Em seus exercícios espirituais, os ascetas religiosos não pretendiam olhar direta e frontalmente para Deus. Praticavam, ao contrário, a contemplação mística, já que no olhar estava subsumido o desejo de enfrentar, apreender, e possuir a coisa olhada. Em seu livro Olhar, Escutar, Ler (1997), Claude LeviStrauss recorda que, a partir do final do século XV, a inalienável abertura da então provinciana Europa para um mundo e um homem inteiramente fora de seu sistema epistemológico desencadeou, entre todas as outras coisas que bem sabemos, uma impossibilidade de se sustentar essa ética medieval do olhar. No momento em que os europeus entendem como novo o mundo que vão descobrindo às margens de suas cartografias, inicia-se certo retorno à acepção grega do verbo scopeîn, que as línguas modernas européias haviam herdado com o sentido heróico de 'mirar', ou seja, fazer do objeto olhado uma mira, um alvo, um desejo, para apreendê-lo, dominá-lo, e melhor explorar seus atributos através do pragmatismo visual. No mito de Medusa, na tragédia de Édipo, na 
biografia de Homero, encontramos exemplos da problemática relação entre o olhar e a audácia humana (hybris), que os Escolásticos conheciam e buscaram controlar.

Diante da pletora imagética que advém com o Novo Mundo, entretanto, esse controle moral acabou por se mostrar não só ineficiente mas sobretudo perigoso para o próprio explorador europeu, já que a liberação do olhar constituiria uma tecnologia básica de autodefesa do sujeito no violento processo que veio a ser a empresa colonial além-mar e sua contraparte de modernização do Velho Mundo. Através dos olhos que aventureiros, exploradores, missionários, cientistas e curiosos lançavam vorazmente sobre todas as coisas "nunca dantes vistas", logrou-se uma reescritura elementar do conhecimento informada pela reeducação óptica e, mais exatamente, através da leitura visual da natureza e do humano num contexto intercontinental.

O que Michel Foucault (1987) chamou entusiasticamente de virada epistemológica do século XVI não passou, a rigor, de uma reorganização do plano topológico da percepção, com o renascimento do discurso sobre o 'lugar de quem olha'. Daí, a liberação moral do olhar ter sido essencial não só para garantir o êxito na dominação daquilo que os europeus iam observando, mas essencial inclusive para formularem uma ideia de si mesmos em escala macro-esférica. Não tardou para que essa ideia de si radicasse numa cultura iluminista, cuja relação com o real está creditada à consciência, conquista e exercício do poder está diretamente associado à visão.

Pois bem: uma vez incorporada a Cobra Norato, a etapa imediatamente seguinte exigida ao herói do poema de Bopp é - direi agora, descartando a oposição inicial entre sonho e realidade - abandonar justamente essa "cultura das luzes" que ele traz consigo. Exige-se, assim, o desarme da chave-mestra de um aparato sensorial sem dúvida estrangeiro e, por suposto, colonizador. Para que esse herói possa se exercer como sujeito no contexto amazônico construído à larga, portanto, é-lhe exigido uma ruptura com seu velho heroísmo; e mais literalmente, com sua herança européia, ou seja, com o modo através do qual aprendeu historicamente a experimentar a realidade e construir um conhecimento sobre ela. Uma ruptura, afinal, com as conquistas epistemológicas de localização de sua própria subjetividade forjada pela moderna técnica do olhar para dar sentido a corpos e fenômenos emergindo fora de sua zona de controle.

Gostaria de ressaltar, a meio caminho, que aquele sujeito forasteiro, desde quando "apaga" os olhos até os versos finais do livro, não fica apenas completamente encoberto pela pele da Cobra Norato. Ele desaparece, por assim dizer, dentro da cobra, sem deixar rastros de quem fora. Ao recriar-se na "pele de seda elástica" (I) do animal 
encantado para partir em busca da filha da rainha Luzia, ele sofre um zoomorfismo como que completa e irreversível, pois está claro que ele não volta a ser quem era ao final da rapsódia, nem segue jornada ao longo do livro simplesmente se disfarçando do animal que enforcou, já que não já, no poema, indícios textuais de uma sensibilidade original desse sujeito por baixo da pela da cobra. Isso confirmaria a ideia de que ele abdica da própria singularidade do corpo estrangeiro e da própria percepção forasteira para assumir o lugar e a sensibilidade subjetiva daquela cobra.

De fato, ao longo do livro, nenhum indício da identidade estrangeira desse herói se manifesta minimamente, nem nas atitudes nem no discurso da voz lírica que assume a rapsódia. Não há nenhum tipo de conflito existencial de subjetividades supostamente incompatíveis ou incongruentes no performance da Cobra Norato enquanto tal. Ela, pelo contrário, exibe uma pronta e plácida segurança de sua identidade ofídia e de ser encantado quando um sapo lhe dirige a questão ontológica que desmascararia o ser: quem és tu? Dizem os versos: “- Quem é você?// - Sou a Cobra Norato/ Vou me amasiar com a filha da rainha Luzia" (IV). ${ }^{3}$

Parece-nos que o poema, agenciando explicitamente o verbo "apagar", requer do sujeito a rasura de sua cultura iluminista que, como sabemos, tende a lançar sobre o que desconhece a rede já fabricada de captura do que supõe que irá reconhecer, determinando-o mais que conhecendo-o em sua potencial novidade e diferença. "Apagar os olhos" nessa zona de contato entre culturas seria, assim, o estranho requisito imposto como uma espécie de 'controle de fronteiras', que garanta, inclusive para fins de defesa estratégica, o desarmamento de um olhar estrangeiro via de regra desbravador e, afinal, exploratório.

Considere-se também o ambiente selvático específico do poema, onde está suspensa uma suposta luminosidade da natureza, aberta ao olhar, e onde não cessam de se rearmar metáforas da "floresta cifrada" (II), através dos signos do obscuro, da sombra, da noite, onde abundam densos lamaçais, tocas de toda sorte de bicho e uma matéria bruta por vezes indiscernível. A par disso, o herói "tem que", peremptoriamente, entrar também numa espécie de escuridão de si mesmo. Se o seu olhar já não lhe deve servir

\footnotetext{
${ }^{3}$ Só momento final do livro, em que a Cobra Norato manda convidar para seu casamento o "povo de Belém de Porto Alegre de São Paulo" (XXXIII), reaparece uma mecha de voz do forasteiro, de uma forma sem dúvida estranha e desconfortável para o leitor que embarcou na aventura da completa zoomorfização do sujeito. Aqui, esse estranhamento dá azo ao que direi adiante: que a lírica traduz muito mais o poeta Bopp do que representa uma tradução dos sujeitos por ele imaginados.
} 
de maneira razoável para equacionar a relação entre o real dentro e fora de si, será preciso que, ante o apagamento da visão, estejam aguçados nele os demais sentidos de que seu corpo ainda dispõe. A interdição da cultura exploratória da modernidade imposta na exigência de que o herói "apague" os olhos implica, afinal, uma segunda reconfiguração subjetiva, como propus acima, conseqüente à ruptura com o ideal iluminista, que desponta no poema como imperativo da experiência tátil e imediatamente física do corpo.

Sigo deste ponto com uma observação: a corriqueira expressão "contato visual" carrega uma contradição interna no mínimo curiosa. Tomando como auto-evidente o fato de que o tato e o paladar são sentidos de efetivo contato, e lembrando que o olfato capta uma emanação gasosa dos corpos enquanto que a audição é antes o registro da fricção entre corpo e ambiente, a percepção visual é, dentre as demais, a única que não implica rigorosamente em nenhum tipo de toque físico. Se o termo "contato" em si mesmo supõe, por etimologia, estabelecer uma aproximação tátil com, numa interação física entre dois corpos, a expressão "contato visual" é, antes de tudo, uma figura que esconde a inegável separação entre matérias, corpos, fenômenos. Aliás, não nos custa reforçar aqui que a visão só é possível na medida em que existe uma descontinuidade entre os corpos, uma distância, um vão que estabeleça o campo visual entre o que olha e o que é olhado.

Isto posto, a interdição que o poema de Bopp impõe ao herói estaria também explicitando, em negativo, o abandono da tradicional construção espacial do olhar, ou seja, a suspensão da diferença de perspectiva entre sujeito e objeto. Levando em conta que, não raro, os seres vivos tendem a desenvolver habilidades especiais com este ou aquele órgão sensorial quando destituídos de outros, mas também quando acometidos de certo bloqueio ou deficiência sensorial específica, não será absurdo supor que, uma vez com os olhos "apagados", o herói terá que aguçar as vias alternativas da percepção. Assim, elidir a visão do sujeito significa tanto desmontar a autoridade daquilo que chamamos 'topologia do olhar', quanto, por conseguinte, acionar uma compensação sensorial, com outro tipo de interação com o real que não será, decerto, à distância, isto é, que será mais imediata à realidade na qual este sujeito se adentra, radicando na experiência direta, tátil, da natureza, no contato efetivo e literal com ela, com seu corpo.

Aquilo que até aqui foi sublinhado como 'exigência' revela trazer, na sua contraface, sem dúvida, uma espécie de 'passagem secreta' no poema, uma discreta abertura, ou um convite intimista, se quisermos, à efetiva interação física do sujeito com a nature- 
za, convertendo aquela possibilidade de exploração em uma verdadeira exposição do corpo ao real.

Nesse passo, não deixa de ser bastante significativo que o sujeito, no zoomorfismo que dá início ao poema, incorpore justamente uma cobra. $\mathrm{O}$ aparelho sensorial dos ofídios é, como sabemos, deficiente no que respeita à visão e afiado no que se relaciona ao tato. Suas línguas bifurcada, além de combinarem receptores palatais e olfativos, também lhes conferem o sentido direcional do odor. Os ofídios possuem, ainda, as chamadas fossetas, seus receptores especiais que lhes permitem perceber o calor emitido por outros corpos. Entrar, portanto, na pele de uma cobra é uma oportunidade extraordinária de reconfigurar seu aparato sensorial e perceber o mundo imediatamente, desde outra subjetividade por esse mundo encantado engendrada.

\section{Ouvir, girar, escrever}

Mas, de onde vem essa voz? A quem ou o quê representa? Onde situá-la na economia do poema?

Há, de saída, a possibilidade de essa voz ser uma espécie de 'auto-consciência' do próprio herói. E tratando-se de um herói no sentido quase inteiramente tradicional, que se mostra ardiloso, vitorioso, surpreendente, talvez pudéssemos chamar essa autoconsciência de 'super consciência', não só porque ela observa o herói desde um plano mais amplo, ou seja, desde cima, ou desde fora, mas por parecer dirigir-se a ele como se ele e essa voz formassem os nós de uma elipse na trama rapsódica, posicionado-o num dos eixos da dinâmica subjetiva em que o discurso varia entre a enunciação direta e a indireta. Essa hipótese de leitura da voz lírico-narrativa do poema ganha decerto um complicador quando consideramos que o herói e essa voz se fundem, logo no início do poema, com a própria Cobra Norato, que o herói estrangula e incorpora. Note-se ainda o gesto do estrangulamento como uma intervenção sobre o centro emissor da voz, e a incorporação da cobra como uma dominação da origem material dessa voz, isto é, do corpo. Assim, Bopp parece querer nos conduzir por um discurso cujo espaço se faz habitado por vozes que se interpenetram e às quais talvez pouco importe se diferenciarem ou se fundirem, já que a questão do domínio pela força e da identidade pela voz não vêm à baila na dramaturgia do poema. 
Talvez possamos falar aqui de uma espécie de fantasmagoria sonora intrometida no discurso lírico, abrindo a hipótese de uma escritura que também mimetiza a própria dimensão mirabolante e 'encantada' de seu espaço selvático na sugestão de uma potencial 'voz da floresta'. E aqui nos vale lembrar o conceito de alucinação auditiva - que Oliver Sacks (2007) sugere para descrever o efeito psíquico de repetição involuntária que certas músicas e ruídos logram operar no cérebro humano - e cogitar, no nível hermenêutico da criação artística, um poeta obcecado por reconstituir a dimensão sensorial daquilo que Bopp teria vivido através da Amazônia que, sabemos, visitou. Não custaria comentar, nessa via, que o sujeito 'obcecado' (que herdamos em português do latim vulgar obcoecare) é, curiosamente, aquele que está cego por causa de uma idéia fixa e, por extensão, aquele que tem a razão obscurecida - 'apagada', para retomar então os próprios termos do poema.

Essa perspectiva do artista simbolicamente cego toca aquilo que Giorgio Agamben (2009) pensa a propósito da noção de 'contemporâneo' na alta modernidade ocidental. Para Agamben, ${ }^{4}$ uma arte contemporânea não é, de saída, aquela que vê o presente desde um lugar de perspectivação privilegiado, mas justamente aquela que não o vê porque se coloca ao nível dos acontecimentos contemporâneos. Dizendo de outro modo, a arte contemporânea não seria exatamente aquela que está sendo produzida nos tempos de agora, mas aquela que, posta no nível mais invisível e cego do agora, capta um 'agora' tão sincronizado com o próprio presente da criação, e por conseguinte com seu próprio tempo histórico, que logra fraturar a própria historicidade desse tempo e ganhar uma atualidade válida para diferentes épocas e lugares, ascendendo à categoria de contemporâneo, digamos, de outras épocas e acontecimentos. Diz o ensaísta:

\footnotetext{
If, as we have seen, it is the contemporary who has broken the vertebrae of his time (or, at any rate, who has perceived in it a fault line or a breaking point), then he also makes of this fracture a meeting place, or an encounter between times and generations. (52)
}

Mas gostaria de enfatizar que o logro dessa fratura, a captação do contemporâneo, depende de não estar numa posição de relevo em relação ao fluxo dos acontecimentos, ou seja, depende de não ser possível 'ver' o presente de uma certa distância, desde um olhar perspectivo; o que redundará, para Agamben, em certa 'cegueira' - ou

\footnotetext{
${ }^{4}$ Cf. Agamben, G. (2009), “What is contemporary?".
} 
ingenuidade, para usar o termo de Schiller - do artista. Assim, captar o 'agora' depende, paradoxalmente, de estar cego para o presente, de ser incapaz de percebê-lo através de uma 'técnica do olhar' por razão mesma de se estar imerso na correnteza dos eventos. E, de tal modo aí imerso, o artista só seria capaz de capturar a fenomenologia do seu presente com sua própria existência, ou seja, sendo parte do fluxo atual do lugar e da época, entranhando-se com ele fisicamente.

$\mathrm{O}$ argumento de Agamben pauta-se, pois, na idéia de que o artista contemporâneo não é aquele que 'revela' o que ninguém foi capaz de ver, mas justamente aquele que esbarra no invisível, com a cegueira de seu corpo, sinalizando por sua vez os pontos cegos não apenas de uma época, mas de todo 'agora', com zonas de invisibilidade de uma espécie de eterno presente: "The contemporary is precisely the person who knows how to see this obscutiry, who is able to write by dipping his pen in the obscurity of the present" (44).

Enquadrando a proposição de Agamben na leitura que temos proposto até aqui de Cobra Norato, podemos dizer que o poema começa por instituir o espaço amazônico enquanto 'zona de invisibilidade'. Para adentrar nele efetivamente, não basta que se visite a região que lhe corresponde, indicada por estudiosos e aventureiros. Será preciso, na verdade, cruzar um portal cultural que corresponde, nos termos de Agamben, a fraturar certa razão espácio-temporal com que se chega e emaranhar-se na materialidade de uma outra correnteza fenomenológica. Desse modo, desentranha-se do poema de Bopp uma sutil advertência aos heróis forasteiros: que não é possível realizar uma autêntica experiência da Amazônia sem esbarrar no 'aqui' e no 'agora' de sua outra historicidade, de sua outra lógica sobre o conhecido e as incógnitas, sem se tornar contemporâneo - e portanto personagem - de suas lendas, sem viver sua irredutível realidade mitológica, sem nos deixarmos roçar por seus bafos e monturos, e sem nos convertemos, enfim, em cegos.

Com isto posto, giro a discussão para o nível hermenêutico da obra, pois creio que esse portal no interior do poema - com a sua dupla face de restrição e convite - ecoa um complexo procedimento de escritura que, como sabemos, foi continuamente revista por Bopp até 1984, quando ele vem a falecer. A história dessa reescritura pode ser redesenhada aqui, para não tardar tanto o debate, em linha reta: o poema começou a ser 
publicado de forma fragmentária em $1927,{ }^{5}$ tendo uma primeira edição oficial coligida em 1931. ${ }^{6}$ Daí em diante teve 9 edições modificadas consecutivamente até 1973, quando sai a $10^{\mathrm{a}}$, ficando esta versão inalterada até a $16^{\mathrm{a}}$, que volta a ser retrabalhada para uma $17^{\mathrm{a}}$ edição, que só veio a ser publicada postumamente, em 1994.

Para pensar a reescritura de Bopp como eco da advertência do início do poema, começo por levar em consideração o fato de que, na $1^{\text {a }}$ edição do poema (1931), o autor havia optado por escrever "fechar os olhos" e, posteriormente, tal como consta na última edição revista, resolveu deixar que o verso comande ao herói “apagar os olhos". Não bastaria ao sujeito lírico, portanto, apenas fechar os olhos para transitar entre duas razões fenomenológicas, mas se transportar do domínio da vigília, onde o sujeito tradicionalmente auto-centrado assumia o controle de si e do que observa, para a esfera do sonho, onde o sujeito descentrado não se demora mais sobre a identidade de seu corpo nem peleja saber de quem são as vozes que emergem em si.

Arrisco-me sugerir, a partir dessa aparentemente banal modificação, que a reescritura do autor está marcando, na sua minuciosa atenção posta sobre o detalhe do verbo escolhido, sua própria sensibilidade para a necessidade de reconfiguração da experiência sensorial em jogo no poema; necessidade esta que ele projeta como desejo na suspensão daquela cultura do olhar que seu próprio eu lírico herda das sociedades litorâneas brasileiras. Refiro-me a 'desejo' aqui, aliás, por interpretar que certo impulso se manifesta em Bopp como força motriz de uma busca continuada de afinar essa cena de suspensão de si, no poema, por meio de um trabalho de reescritura lírica, refletindo também uma espécie de ética dele mesmo, Bopp, a ser partilhada nas entranhas do poema com o leitor - e, mais extensivamente, com todo forasteiro que estiver tentando contato com a Amazônia, tal como o leitor estaria, de algum modo, ao ler esse livro, e tal como Bopp também o está ao revisitar a Hiléia décadas consecutivas no ato simbólico de reescrever de sua obra.

Outro modo de perceber as possibilidades dessa dessa inclinação ética que quero explicitar em Cobra Norato está na substituição de "pussanga de nó de cabelo" na $1^{\text {a }}$ edição para "puçanga de flor de tajá de lagoa" (I) na versão definitiva. Nesta última, a puçanga se atualiza ortograficamente e se torna um artifício mágico mais complexo, seja pelo seu detalhismo figurativo no plano da imagem, seja pela dificuldade do seu

\footnotetext{
5 "Cobra Norato" in Para Todos, Rio de Janeiro, novembro de 1937, p. 36.

${ }^{6}$ Cobra Norato - Nheengatú da Margem Esquerda do Amazonas. São Paulo: Estabelecimento Graphico Irmãos Ferraz, 1931.
} 
acesso material no plano da rapsódia. Mas parece-me que o requinte aproximativo da reescritura, de expandir a complexidade, a raridade, e o alcance desse universo norato, vai além disso.

Salvo melhor juízo contrastivo, a expressão "nó de cabelo" está mais vinculada às magias de substrato nagô e banto, enquanto que "flor de tajá de lagoa" vincula-se sem dúvida à botânica da região e à dinâmica da bacia amazônica. Creio que a mudança de opção sinaliza a percepção de Bopp para essa diferença de substrato cultural, mas sinaliza também - e aqui reside o que considero o mais importante no exemplo - o fato de que a escritura, pelo menos num primeiro momento, ainda utilizava elementos do exotismo vindo de África, que é ainda hoje o que comparativamente circula com mais freqüência no litoral sudeste do Brasil. Minha tese subjacente é a de que esses elementos culturais vindos de África estavam incutidos no imaginário religioso do autor - ou imersos, diria Agamben, numa zona de invisibilidade daquilo que Bopp talvez entendesse, grosso modo, por "mística brasileira".

No plano alegórico da rapsódia, podemos inferir que o herói ainda não estava de olhos plenamente 'apagados'. Mas, em contato permanente com a Hiléia através da reescritura e pesquisa, dar-se-ía, defendo, o aguçar da sensibilidade do autor para a diferença daquilo com que estava lidando. Assim, o poeta redescobre o alcance de sua cegueira e o poema gira: o herói vem a ser um expert na arte de fazer puçangas e de "apagar os olhos" sem qualquer vulnerabilidade, sem nenhum medo. Na reescritura do poema, assim, notar-se-á outros esforços deliberados de abandono do imaginário litorâneo herdado, que parece ter servido de padrão para acionar, como no exemplo acima, uma outra magia específica e ainda forasteira, cuja força mimética o autor provavelmente percebeu que não desmontaria o aparato subjetivo de um herói de fora da Amazônia para lhe conferir heroísmo efetivo dentro dela.

Nesse sentido, reescrever Cobra Norato ao longo de várias décadas seria, inclusive por conta de seu caráter obsessivo, um exercício de infinita aproximação do autor ante seu objeto, em busca de realizar, no limite, um contato de tal forma efetivo, etnológica e sensorialmente, que tomaria a Amazônia não mais como objeto mas a converteria em co-sujeito da escritura mesma, como se o cegar-se para as imagens e narrativas locais correspondesse a uma espécie de entrega (como que ritual) do próprio corpo a uma cultura; uma cultura que, a partir daí, dessa entrega, será o guia nessa jornada lírica por meandros de águas, e vozes incógnitas, e tramas de cipós cheios de personalidade. Nesse limite digamos transcendental que lembraria uma alucinação xamânica, o 
sujeito obcecado e o sujeito obsessivo se cruzariam no ponto exato em que a própria Hiléia parecesse uma co-autora do poema.

Julgo eu que o intento de Bopp com esse livro não era, assim, trazer o Brasil selvagem para o Brasil civilizado, canibalizando-o segundo o programa do Manifesto Antropófago (1928), mas fazer do poema uma encruzilhada não-mediada entre estes dois brasis, ou seja, um espaço de cruzamento imediato entre a realidade 'encantada' da Hiléia, que de tão movediça parece escapar dos condicionamentos do discurso mitológico, e a lírica 'rebelde' da vanguarda modernista, que de tão exímia parece ludibriar o próprio princípio da invenção estética do real e defender que "A poesia existe nos fatos" ${ }^{7}$. Nesse espaço, o poeta não se apresentaria como aquele supostamente neutro intérprete do Brasil, nem o poema serviria de meio de transmissão de um determinado saber supostamente desejado e aí embutido, mas ambos, poeta e poema, se tornariam eixos elípticos, como propus acima, de uma experiência de rotação em torno de um espaço antipático ao senso de realidade construído a partir de certa tradição do olhar.

Ao abdicar dessa lógica - que aliás foi a prática corrente (e nem sempre confessa) do primeiro modernismo nacional - Bopp propõe um pacto de leitura absolutamente outro que, penso, desvincula a obra do mainstream de apropriação canibal que orientou o projeto oswaldiano, pelo menos em termos de uma ideologia estético-política cujo substrato colonialista, de conquista e pilhagem cultural do Brasil 'desconhecido' se faz por vezes tão evidente para o leitor.

\section{Traduzir, revelar, esconder}

Sigo, portanto, na contramão do modo como Lúcia Sá (2004) lê Cobra Norato e o projeto boppiano aí implicado, quando afirma que, se Bopp...

\footnotetext{
was able to recognize the existence of another sensitivity or even another "world" [...], he could not (or perhaps did not wish to) translate/cannibalize that world into poetry, except through the filter of an overpoweringly Southern poetic "I". (220)
}

Discordo, a partir do que demonstrei anteriormente, que o poeta tenha se afincado e permanecido fiel à doutrina antropofágica durante os mais de 50 anos que foi sua atividade literária. Até a última versão do poema, aquele procedimento simbólico de

\footnotetext{
${ }^{7}$ Trata-se da primeiríssima linha do Manifesto da Poesia Pau-Brasil, também de Oswald de Andrade.
} 
devora, que lembra a fase oral freudiana na formação do sujeito no indivíduo, transforma-se - ou evolui, pensando junto com Freud - tão radicalmente que podemos dizer que acaba por ser abandonado por completo nas décadas seguintes. Não percebo se tratar pois de uma questão dicotômica entre falha ou êxito no cumprimento da doutrina vanguardista, mas de uma continuada, intensa e verificável mudança de projeto estéticopolítico, expresso na abdicação do ponto de vista do herói - ou uma recusa do poeta a ter pontos de vista, nos termos do poema - sobre o trabalho de cruzar lírica e estranhamento em territórios amazônicos.

O que havia sido articulado por Oswald de Andrade nos "Manifestos" como técnica de criação e atitude política a ser adotada nacionalmente reifica a Amazônia como estranheza e o exotismo que deve ser agregada ao projeto nacionalizante da cultura litorânea, imputando-lhe uma liderança no gesto de percepção da diferença, e não de sua efetiva "incorporação", como Bopp leva seu herói a fazer com a cobra. Como as constantes reescrituras do poema dão notícia, Bopp começa por recusar a idéia de que a Amazônia é um espaço tão estrangeiro quanto o é o Velho Mundo, a ponto de ter sido preciso (e, antes, possível) mediá-lo, ou ‘traduzi-lo’ tal qual Lúcia Sá sugere a propósito da intenção estética do autor como intelectual público. Inclino-me a crer que deixou de ser esse o propósito do autor no arco do tempo. Para Bopp, o estranhamento da Hiléia se revelou necessariamente outro, ou de outra categoria que não simplesmente a do exótico, e por isso agenciou aos bocados uma outra dinâmica de leitura e reescritura, o que para o poema significou agenciar outro herói, com outro corpo, com olhos que se apagam em vez de se fecharem apenas. E, para o poeta, significou agenciar outro princípio de criação.

Nesse sentido específico, capturar tal princípio sob uma ideia de 'tradução' soa bastante inapropriado, não apenas porque insiste naquela distância espacial que Bopp se esforçou para elidir, mas sobretudo porque pressupõe monoliticamente todos os jogos de poder, saber e representar que estão implicados na tarefa do tradutor, como bem nos lembra Lori Chamberlain (1988): "The reason translation is so overcoded, so overregulated, is that it threatens to erase the difference between production and reproduction which is essential to the establishment of power" (314).

Chamberlain nos interessa aqui, portanto, porque amplia as possibilidades de debate sobre a produção textual primária e secundária através do deslocamento do problema da tradução desde sua tradicional validade enquanto produção de documento dotado de poderes próprios que competem com a autonomia da criação, e portanto fra- 
giliza o circuito do poder que hierarquiza a representação e a cópia num patamar abaixo do original. Nesse debate, a autora explicita que as metáforas da tradução revelam, por um lado, a vontade de manutenção dos mitos de paternidade que a autoria exerce diante da cópia, e por outro lado, uma repetição das lutas simbólicas de poder dentro do triângulo edipiano que constituiu o modelo de afirmação da auto-consciência da subjetividade ocidental. Para que em ambos os planos a tradução logre sucesso, Chamberlain conclui que seria preciso "devorar o pai", ou seja, realizar, nos termos oswaldianos, uma inescapável "tradução canibalística" (312).

Ora, se bem observado, o argumento da autenticidade não se aplica a Cobra Norato por conta de que Bopp não se empenha, em nenhuma etapa das múltiplas revisões que fez do poema, em reproduzir a lenda mesma da Cobra Norato, nem em fazer um arrazoado das inúmeras versões orais que desta teve notícia. Só obliquamente - e julgo que de forma deliberada - o poema recupera certas passagens desses relatos, investindo mais na atmosfera sensorial que na fidelidade dos eventos. Em seu poema, Bopp não conta, afinal, nenhuma lenda, mas imagina-a, como um contemporâneo dela, ou seja, imaginando a si mesmo, insisto nisso: com e desde uma 'visão apagada' de seu herói, imerso na credibilidade dos relatos e sua potência em fraturar a realidade forasteira, ao nível de seus sentidos, de suas percepções.

O que o poeta faz não seria, por nada, uma antropofagia, nem no sentido da possessão ansiosa do que lhe é exótico, nem no sentido da colagem carnavalesca de histórias que ouviu e não sabe bem onde. O poema, por isso, não é um 'produto' no sentido de texto, mas o operador de uma textura, no sentido sensorial que antecede o discurso do texto, digo, do corpo, pois produz uma experiência de subjetivação longitudinal através da reescritura que o imaginário da Amazônia nele provocou. Só nesse sentido, creio, seria plausível redistribuir os poderes da voz lírico-narrativa e atribuir ao poema um valor de 'tradução'; ou seja, o poema valeria como tradução apenas na cuidadosíssima medida em que a obra representa não uma Amazônia 'encantada', ou o Encante, mas o poeta mesmo em seu contínuo trabalho de identificação com um herói que "apaga os olhos" ao invés de ver aonde se mete; trabalho este que Bopp faz por meio da sutil revisão e reescritura de sua experiência específica de subjetivação diante da Hiléia.

A requintada modernidade de Raul Bopp, que faz dele um artista rigorosamente contemporâneo, reside justamente nessa subversão do sistema epistemológico do discurso do poder de que nos fala Chamberlain, esticando "a pele de seda elástica" da criação, ao puxar ao avesso a lógica antropófaga de Oswald de Andrade, e se tornar ele 
mesmo sujeito da antropofagia, inclusive na ação intestina do herói que desaparece dentro de uma cobra, mas sobretudo no emaranhar-se nas interrogações suspensas por galhos e informantes, deixando-se cegar e guiar por vozes e sombras, seguindo numa reescritura quase sem fim, sensível ao detalhe mais interessado no exercício ético de infinita aproximação da "matéria movente" da Amazônia através do trabalho longitudinal e discreto de reescritura.

Se quisermos insistir, portanto, em pensar o triângulo Amazônia-Cobra NoratoBopp numa ética heterodoxa ou subversiva da tradução, eu diria em linha reta que a Amazônia seria a tradutora, o poeta seria a tradução, e o poema seria o mirabolante operador que aproxima um do outro continuamente, assombradamente, e talvez sem limites, se em sua circularidade lírica parece simular mesmo a própria Uroborus, a cobra mística que engole o próprio rabo, tomada pelos mestres da alquimia como símbolo do infinito.

Através destas considerações, gostaria de pensar o poema de Bopp mais especificamente como "crítica da mediação", como sugeri acima. Com esse termo, pretendo ressaltar a possibilidade de uso do termo 'tradução', tal como proposto por Lúcia Sá no âmbito de Cobra Norato, por exemplo, apenas de forma relativa, ressituando e reteorizando esse termo inteiramente. E também como Bopp, no ato mesmo da minha leitura, procuro dar a este ensaio uma maneira alternativa (e um tanto experimental no que tange às suas margens de discussão) de lidar com um procedimento de interpretação aplicado esteticamente pelo intelectual moderno de maneira, creio, original e digna de esforços de teorização.

Como procurei demonstrar, a modernidade de Raul Bopp reside justamente no subverter a tendência mediadora dos artistas de seu círculo intelectual das décadas de 1920 e 1930, que adotaram, sob muitos aspectos, um programa estético cheio de desavisados laivos neocolonialistas. Essa subversão de Bopp, fundamentada numa ética amadurecida da experiência de contínua revisitação de seus temas, isto é, das incógnitas da Amazônia, radicou na reescritura de um poema que acaba por operar uma reconfiguração na subjetividade lírica do autor, transformando-o em metonímia do que se exige do herói, e por sua vez, sem dúvida, do leitor. Ler Cobra Norato seria, nessa medida, reconfigurar certa herança sensorial e discursiva. Nesse jogo de espelhamento subjetivo invertido, o corpo do poema funciona como um campo simbólico onde Hiléia e poeta se cruzam e se ressignificam como co-sujeitos.

O poema não seria assim, metaforicamente, uma tradução que Bopp faz da Amazônia, mas a interface que traduz essa co-subjetividade que poema e matéria poética 
formam. Ou, se quisermos retomar Chamberlain, a técnica de aproximação entre os dois sujeitos que partilham um mesmo discurso sem possuí-lo. Ao adotar esse princípio criacional que faz da criatura o criador, sujeito e objeto perdem sua diferença ontológica e se transformam ambos em criaturas. Tanto o poeta quanto a matéria poética passam a ser obras do poema.

Essa estratégia de leitura aqui proposta, que pode incomodar como uma pirueta intelectual, emerge e tenta dar conta, na verdade, de uma audácia lírica, sem dúvida mirabolante, realizada por Bopp como uma 'crítica da mediação' porque seu procedimento básico de descentrar a lógica do sujeito vai questionar os parâmetros do poder e do saber implicados na mediação mesma que ele, Bopp, supostamente conduziria.

A literatura de Bopp desconfiou da tradicional interpretação do Brasil na via contrária dos renomados modernistas brasileiros, ou seja, desconfiou do espanto do Brasil 'civilizado' e sobre este espanto investiu sua escritura. Ao reelaborar Cobra Norato, o poeta se recusou a tomar a escritura como representação tácita do mundo, como mediação cultural entre uns e outros. Seu trabalho aponta, como não cessei de apontar eu mesmo, para o desejo de contato imediato entre singularidades subjetivas que acaso se percebam diferentes ou distantes. E se pensarmos que o trabalho de qualquer crítico é antes e sobretudo uma experiência continuada de leitura, arriscaria sugerir que Bopp estaria fazendo, ainda, um convite ao 'leitor sem olhos' entrar no poema com outro corpo, numa reafirmação de que a Cobra Norato, enquanto 'poema tátil', possui uma textura e uma dimensão sensorial que precisa ser lida em um equivalente ao sistema braile.

No poema, portanto, a questão da tradução canibalesca não se coloca à risca porque o texto amazônico se mantém irredutivelmente ilegível para aquele leitor que não fechar os olhos para a idéia tradicional de mediação, correndo o risco de criticar o poema de Bopp enquanto produto experimental de um "avassalador sujeito poético sulista”, como entendeu Lúcia Sá. E, ainda, enquanto operação literária que re-opera o sentido da própria literatura, Cobra Norato serve de portal para imaginarmos nós mesmos uma Hiléia incógnita e invisível que só se subjetiva em nós mesmos.

Dessa forma, faço uma última consideração sobre a subversão que Bopp opera no imperativo modernista da Antropofagia. Se o 'homem moderno' não devora a cobra encantada porque é simbolicamente devorado por ela, na medida em que se submete à sua pele e se adapta a seu lugar e a sua voz, rasurando a velha subjetividade litorânea ou européia, a contemporaneidade de Bopp residiria sobretudo na habilidade de fraturar o fluxo ideológico do Modernismo, e alçar (ou, de novo, "esticar") o poema para a cate- 
goria de tradutor de uma cegueira nacional que a Amazônia decerto metonimiza para o Brasil: o imperativo exógeno da identidade. Assim, através da contemplação e não do provimento de respostas para a incógnita da imagem nacional, direi que Bopp inverte o lema "revelar o Brasil para o brasileiro" no exercício de revelar-se a si mesmo como brasileiro ao Brasil.

\section{Works Cited}

AGAMBEN, Giorgio. What Is an Apparatus?: And Other Essays. Stanford, CA: Stanford UP, 2009.

BOPP, Raul. Cobra Norato; Nheengatú Da Margem Esquerda Do Amazonas. São Paulo: Estabelecimento Graphico Irmãos Ferraz, 1931.

. Cobra Norato. Rio De Janiero: José Olympio Editora, 1998.

CHAMBERLAIN, Lori. "Gender and the Metaphorics of Translation", in VENUTI, Lawrence (org.). The Translation Studies Reader. London: Routledge, 2004. pp. 306321.

DE ANDRADE, Oswald. Manifesto Antropófago e outros textos. Org.: Jorge Schwartz \& Gênese Andrade. São Paulo: Cia. das Letras, 2017.

FOUCAULT, Michel. As Palavras E as Coisas: Uma Arqueologia Das Ciências Humanas. São Paulo, SP, Brasil: Martins Fontes, 1987.

SÁ, Lúcia. Rain Forest Literatures: Amazonian Texts and Latin American Culture. Minneapolis: University of Minnesota, 2004.

SACKS, Oliver W. Musicophilia: Tales of Music and the Brain. New York: Alfred A. Knopf, 2007.

Recebido em 24/05/2018

Aprovado em 01/07/2018 